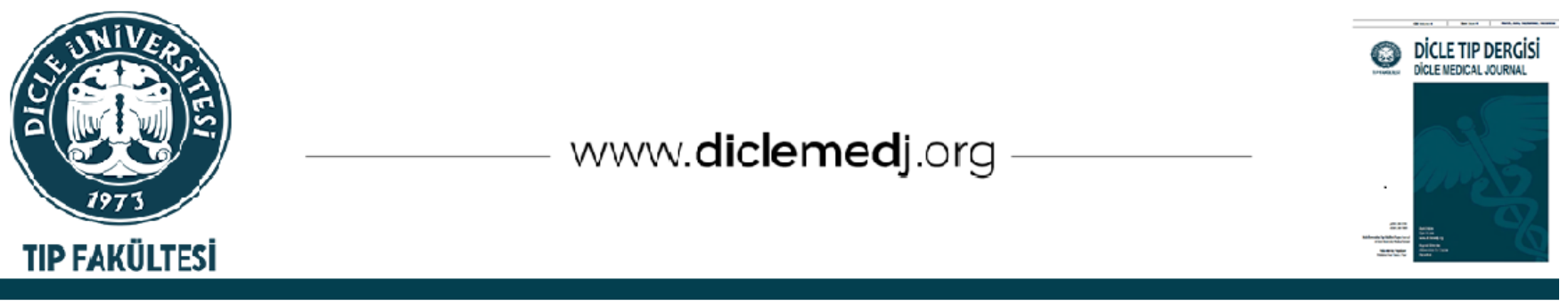

\title{
COVID-19’lu Hastalarda Tedaviye Bağlı Karaciğer Hasarı Gelişme Sıklığı, Favipravir bu Tabloda ne Kadar Etkili?
}

\author{
Berat Ebik ${ }^{(D}{ }_{1}$, Nazım Ekin ${ }^{1}{ }_{1}$ Ferhat Bacaksız ${ }^{(1}{ }_{1}$ Jihat Kılıç ${ }^{i D_{2}}$ \\ 1 SBÜ Diyarbakır Gazi Yaşargil EAH Gastroenteroloji Bölümü Diyarbakır,Türkiye \\ 2 SBU Diyarbakır Gazi Yaşargil EAH, İç Hastalıkları Kliniği, Diyarbakır, Türkiye \\ Geliş: 03.11.2020; Revizyon: 28.04.2021; Kabul Tarihi: 30.04.2021
}

Öz

Amaç: Çalışma amacımız; COVID-19 tedavisinde kullanılan ilaçların karaciğer fonksiyon testleri üzerindeki etkisini incelemek ve hastalarda tedavi sırasında ilaca bağlı karaciğer hasarı (İBKH) gelişim sıklı̆̆ını araştırmaktır. Ayrıca literatürde karaciğer üzerindeki etkisiyle ilgili çok fazla veri olmayan favipravirin; COVID-19 tedavisinde yaygın bir şekilde kullanılmaya başlanmasıyla gelişen karaciğer fonksiyon bozukluklarının favipravir ile ilişkisini araştırmaktır.

Yöntemler: Çalışmamıza 2020 Nisan-Eylül döneminde PZR (polimeraz zincir reaksiyonu) testi ile COVID 19 tanısı konulan ve hastanede yatarak tedavi gören 1301 hasta aldık. Önceden bilinen kronik karaciğer hastalığı olanları, COVID19 sırasında sitokin fırtınası, sepsis ve iskemik hepatit gelișen hastaları çalışmaya almadık. Hastaları kullandıkları ilaç tedavisine göre gruplara ayırdık. Gruplar arasında, karaciğer fonksiyon bozukluğu ve İBKH gelișen vaka sayısında fark olup olmadığını inceledik.

Bulgular: Çalışmaya aldığımız 1301 hastanın \%50.2 sinde tedavi sırasında ALT-AST yüksekliği gelişmesine rağmen bu yüksekliklerin \%45.3'ünün hafif ve orta düzeyde enzim artışı olduğu görüldü. Hastaların \%4,9'unda İBKH gelişti. Sadece favipravir alan hastaların \%1,1'inde İBKH gelişmesine karşın; favipravir+antibiyotik alan hastalarda bu oran \%8,7 idi. $(p<0.001)$. Benzer şekilde hastaların \%14'ünde ALP, \%48,1'inde GGT yüksekliği gelişti. Favipravir+antibiyotik alan hastaların \%17,5'inde ALP, \%51,8'inde GGT yüksekliği gelişirken sadece favipravir alan hastaların \%4,3'ünde ALP, \%40,1'inde GGT yüksekliği tespit edildi.(ALP için p<0.001,GGT için $\mathrm{p}<0.001$ )

Sonuç: COVID-19 tedavisi sırasında her iki hastanın birinde karaciğer fonksiyon testlerinde bozulma meydana geldi. Karaciğer enzimlerini en çok yükselten ve İBKH'a en çok neden olan ilaçların favipravirden daha çok antibiyotikler olduğunu belirledik. Tedavi sırasında hepatik veya kolestatik tipte karaciğer fonksiyon bozukluğu gelişen hastalar yakın takip edilmeli, potansiyel hepatotoksik ilaçlar erken kesilmeli ve İBKH gelişimi engellenmeye çalışılmalıdır.

Anahtar kelimeler: COVID-19, ilaca bağlı karaciğer hasarı, favipravir

DOI: 10.5798/dicletip.944397

Yazışma Adresi / Correspondence: Berat Ebik, SBÜ Diyarbakır Gazi Yaşargil EAH Gastroenteroloji Bölümü Diyarbakır, Türkiye, e-mail: beratebik@gmail.com 


\title{
The Frequency Of Development Of Liver Damage Related To Treatment in Patients With COVID-19, How Favipravir is Effect On This Situation?
}

\begin{abstract}
Objective: Our working purpose; was to examine the effect of drugs used in the treatment of COVID-19 on liver function tests and to investigate the frequency of development of DILI (drug-induced liver damage) during treatment in patients. In addition, there is not much data in the literature regarding the effect of favipravir on the liver; liver function disorders caused by the widespread use in the treatment of COVID-19; to investigate its relationship with favipravir.

Methods: We included 1301 patients who were diagnosed with COVID-19 by PCR test and were hospitalized in our study between April-September -2020. We did not include patients with previously known chronic liver disease, those who developed cytokine release syndrome during COVID-19, and patients who developed sepsis and ischemic hepatitis. We divided the patients into groups according to the medication they used. We examined whether there was a difference in the number of cases with liver dysfunction and DILI between the groups.

Results: ALT-AST elevation developed in $50.2 \%$ of the 1301 patients we included in the study during the treatment. $45.3 \%$ of this increase was mild and moderate enzyme elevation. DILI developed in $4.9 \%$ of the patients. DILI developed in $1.1 \%$ of the patients who received only favipravir, while the rate of DILI development was found to be $8.7 \%$ in patients who received favipravir + antibiotics. ( $\mathrm{p}<0.001)$ Similarly, $14 \%$ of the patients had ALP and $48.1 \%$ had GGT elevation. Although $17.5 \%$ of the patients who received favipiravir + antibiotics had ALP and $51.8 \%$ had elevated GGT, $4.3 \%$ of the patients who took only favipiravir had ALP and 40.1\% had an elevation of GGT. (P<0.001 for ALP, $\mathrm{p}<0.001$ for GGT)
\end{abstract}

Conclusion: During COVID-19 treatment, liver function tests deteriorated in one of both patients. We determined that the drugs that increase liver enzymes the most and cause DILI the most are antibiotics rather than favipiravir.

Keywords: COVID-19, drug-induced liver damage, favipravir.

\section{GíRiş}

Koronavirüs hastalığı (COVID-19) tüm dünyayı etkisi altına alarak, şu ana kadar tespit edilebilen en az 100.000.000 vakaya ve 2.000.000'dan fazla kişinin ölümüne neden olmuştur $^{1}$. COVID-19; hafif solunum yolu belirtilerinden, şiddetli pnömoniye, ağır solunum yetmezliği sonucu multiorgan disfonksiyona kadar çok geniş bir klinik yelpazeyle karşımıza çıkmaktadır. COVID-19 hastalığına yönelik doğrudan etkili bir tedavi olmadığından dolayı bugüne kadar 30'a yakın ilaç koronavirüs tedavisinde denenmiștir². Çeşitli antibiyotikler, antiviral ilaçlar, steroidler, monoklonal antikorlar, kolşisin, $\mathrm{H} 2$ reseptör blokerleri, antihistaminikler, plazma tedavisi, mezenkimal kök hücre tedavisi, antikoagülan ilaçlar, vitaminler her ülkenin hatta her kliniğin kendi pratiğine göre genellikle bir kokteyl şeklinde uygulanmaktadır. COVID-19 tedavisinde kullanılan bütün bu ilaçların değişik oranlarda hepatotoksik potansiyeli mevcuttur.
Özellikle bu ilaçlar birlikte kullanıldığında bu risk daha da artmaktadır.

İBKH(ilaca bağlı karaciğer hasarı), yaygın ve ciddi advers ilaç reaksiyonlarından biridir. Şiddetli İBKH olguları akut karaciğer yetmezliği, fulminan hepatit ve ölümle sonuçlanabilir³. Akut İBKH olguları birkaç gün ile birkaç ay sürerken süreç uzadıkça hastada kronik hepatit, karaciğer fibrozisi ve kalıcı safra yolu hasarı gelişme riski artmaktadır ${ }^{4}$.

Favipiravir Japonya'da influenza için geliştirilmiş bir ilaç olmasına rağmen COVID-19 salgınıyla birlikte, bu hastalarda dünya genelinde yaygın bir şekilde kullanılmaktadır. $\mathrm{Bu}$ ilaç viral genomların transkripsiyonu ve replikasyonu için gerekli olan RNA'ya bağımlı RNA polimeraz (RdRp) enzimlerini hedefler ${ }^{5,6}$. Daha önceden ebola virüsü, lassa virüsü gibi viral enfeksiyonlarda etkisi araştırılmıştır 7,8 . Favipravirin karaciğer üzerindeki etkileriyle ilgili veriler çok sınırlıdır. Kullanım bilgisinde 
hafif ve orta karaciğer hasarında herhangi bir doz ayarlaması tavsiyesinde bulunulmazken, şiddetli karaciğer hasarı gelişen hastalarda kullanımının kontrendike olduğu belirtilmektedir 9 .

Biz de hastanemize COVID-19 tanısıyla yatırılan hastaların tedavi sürecinde ne kadarında karaciğer fonksiyon testlerinde değișiklikler meydana geldiğini ve gelişen İBKH vakalarında favipravirin etkisinin olup olmadığını araștırdık.

\section{YÖNTEMLER}

Çalışmamıza 2020 Nisan-Eylül tarihleri arasında PZR (polimeraz zincir reaksiyonu) testi ile COVID-19 tanısı konulan ve hastanede yatarak tedavi gören 1301 hasta alındı. Çalışmaya başlamadan önce Sağlık Bakanlığından izin ve hastanemiz etik kurulundan onay alındı. (Bakanlık izin No2020-06-05T10-40-24; Etik kurul: 16.10.2020 tarih ve 611 sayılı karar). Daha önceden bilinen kronik karaciğer hastalığı tanısı olan, sitokin fırtınası ve sepsise bağlı karaciğer hasarı gelișen, karaciğer transplantasyon hastaları, immunsupresif tedavi alan, malignitesi olan ve septik șoka bağlı iskemik karaciğer hastalığı gelişenler vakalar ile COVID-19 bulguları olan fakat PZR testi negatif olan hastalar çalışmaya alınmadı.

Hastaları, COVID-19 tedavisi için favipravir almayan ve hidroksiklorokin ile birlikte antibiyotik alan (grup1), sadece favipravir alanlar (grup2) ve favipravir ile birlikte en az bir antibiyotik alan (grup3) hastalar olmak üzere 3 gruba ayırdık. Bu hastaların takipleri sırasında gelişen karaciğer fonksiyon bozukluklarını inceledik.

COVID-19 tedavisine bağlı İBKH gelişen hastaları EASL 2019 kılavuzuna göre (ALT $\geq 5 \times$ NÜS (normalin üst sinırı) veya ALP $\geq 2$ ULN yükselmesi (bilinen kemik patolojisinin yokluğunda) veya ALT $\geq 3$ ULN yükselmesi ile aynı anda toplam bilirubin konsantrasyonunun
$2 \times$ ULN'yi aşan yükselmesi kombinasyonu) belirledik ${ }^{10}$.

\section{İstatistik}

Verilerin normal dağılım gösterip göstermediği Shapiro-Wilk testi, varyasyon katsayısı, Skewness ve Kurtosis testleri ile kontrol edildi. Sürekli değisşenler ortalama ve standart sapma ile belirtilirken kategorik değişkenlerde \% ve sıklık belirtildi. Normal dağılan parametrelerde ortalama ve standart sapma belirtilirken, normal dağılmayan parametrelerin ise median, minimum ve maximum değerleri belirtildi. COVID-19 hasta gruplarında varyansları homojen olan gruplarda 2 yönlü anova testi yapıldı. Hangi gruplar arasında anlamlı fark olduğunu tespit etmek için bonferroni düzeltmesi kullanıldı. Varyansları homojen dağılmayan gruplarda Kruskal-Wallis testleri yapıldı. Tüm testler çift taraflı olup p değeri < 0.05 istatistiksel olarak anlamlı kabul edildi. İstatistiksel analizler SPSS26.0 for Windows (SPSSInc.Chicago,IL,USA) paket programı kullanılarak yapıldı.

\section{BULGULAR}

Çalışmaya aldığımız 1301 hastanın 636'sı kadın(\%46,6), 665'i erkekti(\%53,4). Hastaların yaş ortalaması 51.38 19.68 idi. (8-100) (Tablo1).

Tablo I: Çalış̧aya alınan COVID-19'lu hastaların gruplara göre dağllımı ve demografik verileri

\begin{tabular}{|ccccc|}
\hline Favipravir & $\begin{array}{c}\text { Sadece } \\
\text { almayan }\end{array}$ & $\begin{array}{c}\text { Favipravir+antibiyotik } \\
\text { favipravir }\end{array}$ & Total \\
$\mathbf{N}$ & 449 & 257 & 595 & 1301 \\
Yaş & $43.63 \pm 18.38$ & $60.1 \pm 16.06$ & $62.8 \pm 16.0$ & $51.38 \pm 19.68$ \\
& $(8-97)$ & $(21-90)$ & $(21-100)$ & $(8-100)$ \\
Kadın & 220 & 111 & 276 & $607(\% 46,6)$ \\
& 229 & 146 & 319 & $694(\% 53,4)$ \\
Erkek & & & &
\end{tabular}

COVID-19 tedavisi alan hastalarda transaminaz değerlerinde en çok artış favipravir+ antibiyotik kullanan hastalarda görüldü. En az artışın ise sadece favipravir kullanan hastalarda olduğu tespit edildi. Gruplar arasındaki bu enzim farkı 
istatistiksel olarak anlamlı idi. Kolestaz kullanan hastalarda favipravir olsun veya göstergeleri olan ALP ve GGT seviyesi bütün gruplarda artış gösterdi. ALP ve GGT olmasın daha ciddi yükseklikler saptandı. seviyesinde en az yükselme sadece favipravir alan hastalarda izlendi. Özellikle antibiyotik Bilirubin seviyesinde gruplar arasında anlamı fark saptanmadı (Tablo-2).

Tablo II: Hastaların tedavi öncesi ve sonrası laboratuvar değerleri

\begin{tabular}{|c|c|c|c|c|c|c|c|c|}
\hline & & $\begin{array}{l}\text { ALT(IU/L) } \\
\text { (tedaviden } \\
\text { önce) }\end{array}$ & $\begin{array}{l}\text { ALT(IU/L) } \\
\text { (Tedavi } \\
\text { sonu) }\end{array}$ & $\begin{array}{l}\text { AST(IU/L) } \\
\text { (Tedaviden } \\
\text { önce) }\end{array}$ & $\begin{array}{l}\text { AST(IU/L) } \\
\text { (Tedavi } \\
\text { sonu) }\end{array}$ & ALP(IU/L) & GGT(IU/L) & $\begin{array}{l}\text { Bilirubin } \\
\text { (mg/dl) }\end{array}$ \\
\hline & $\begin{array}{l}\text { Favipravir } \\
\text { almayan(Grup-1) }\end{array}$ & $18.76 \pm 17.08$ & $42.63 \pm 91.89$ & $16.38 \pm 17.45$ & $44.28 \pm 71.89$ & $69.3 \pm 40.12$ & $60.75 \pm 48.33$ & $0.59 \pm 0.33$ \\
\hline & $\begin{array}{l}\text { Sadece favipravir } \\
\text { alan(Grup-2) }\end{array}$ & $19.24 \pm 11.47$ & $29.84 \pm 23.92$ & $17.33 \pm 8.17$ & $30.65 \pm 23.87$ & $62.53 \pm 23.86$ & $51.79 \pm 38.47$ & $0.54 \pm 0.36$ \\
\hline \multirow{3}{*}{$\begin{array}{l}\text { P } \\
\text { değeri }\end{array}$} & Grup1-Grup2 & 0.803 & 0.003 & 0.401 & 0,101 & 0.120 & 0.280 & 0.469 \\
\hline & Grup 1-Grup 3 & 0.543 & 0.001 & 0.669 & 0.009 & 0,080 & 0,006 & 0.405 \\
\hline & Grup 2-Grup 3 & 0.457 & $<0.001$ & 0.250 & 0.001 & $<0.001$ & $<0.001$ & 0.071 \\
\hline
\end{tabular}

Her 3 grup arasında 2 yönlü anova testi yapılmıştır. Gruplar arası Varyansları homojen dağılanlara bonferoni, homojen olmayanlara ise Tamhane testi yapılmıștır.

COVID-19 tedavisi alan $648(\% 49,8)$ hastanın ALT-AST değeri normalken 653 hastada $(\% 50,2)$ değişik derecelerde karaciğer enzim yüksekliği gelişti. Hastaların \%38,3'ünde 1-3 kat arası, \%7'sinde 3-5 kat arası ALT-AST yüksekliği gelişirken; tüm hastaların \%4,9'unda İBKH gelişti. En yüksek İBKH gelişim oranı \%8,7 ile favipravir+antibiyotik alan gruptaydı. En düşük İBKH gelişim oranı sadece favipravir alan gruptaydı. $(\% 1,1)$ Dikkat çeken bir diğer nokta favipravir+antibiyotik alan hastaların sadece $\% 28,1$ 'inde karaciğer fonksiyonları normal kalabilmişti. Bu hastaların \%71,9'unda değișen derecelerde ALT-AST yüksekliği saptandı (Tablo-3).

COVID-19 tedavisi alan 1301 hastanın 183'ünde (\%14) ALP yüksekliği gelişti. Favipravir+antibiyotik alan hastaların \%17,5'inde ALP yüksekliği gelişirken sadece favipravir alan hastalarda bu oran \%4,3 idi. $(\mathrm{p}<0.001)$ GGT yüksekliği ise hastaların \%48,1'inde tespit edildi. Yine favipravir+antibiyotik alan hastalarda bu oran $\% 51,8$ iken sadece favipravir alan grupta bu oran $\% 40,1$ olarak saptand 1 ( $\mathrm{p}<0.001$ ) (Tablo4).

Tablo III: COVID-19 tedavisi alan hastalarda tedavi sonrası gruplar arası ALT-AST yüksekliği gelişme oranları

\begin{tabular}{|c|c|c|c|c|c|}
\hline ALT/AST & Normal & 1-3 kat & 3-5 kat & $>5$ kat & $\begin{array}{l}P \\
\text { değeri }\end{array}$ \\
\hline $\begin{array}{l}\text { Favipravir } \\
\text { almayan } \\
\text { (n:449) }\end{array}$ & $292(\% 65)$ & $132(\% 29.4)$ & $16(\% 3.6)$ & $9(\% 2)$ & \multirow{4}{*}{$\begin{array}{l}< \\
0.001\end{array}$} \\
\hline $\begin{array}{l}\text { Sadece } \\
\text { favipravir } \\
\text { (n:257) }\end{array}$ & $189(\% 73.6)$ & $55(\% 21.4)$ & $10(\% 3.9)$ & $3(\% 1.1)$ & \\
\hline $\begin{array}{l}\text { Favipravir } \\
\text { +antibiyotik } \\
\text { (n:595) }\end{array}$ & $167(\% 28.1)$ & $311(\% 52.3)$ & $65(\% 10.9)$ & $52(\% 8.7)$ & \\
\hline $\begin{array}{l}\text { Toplam } \\
\text { (n:1301) }\end{array}$ & $648(\% 49.8)$ & $498(\% 38.3)$ & $91(\% 7)$ & $64(\% 4.9)$ & \\
\hline
\end{tabular}

Kruskal Wallis testi uygulanmıştır. 
Tablo IV: COVID-19 tedavisi alan hastalarda tedavi sonrası gruplar arası ALP-GGT yüksekliği gelişme oranları

\begin{tabular}{|llll|}
\hline & & ALP $^{*}(\mathrm{IU} / \mathrm{L}$ & GGT*$^{*}(\mathrm{IU} / \mathrm{L})$ \\
$\begin{array}{l}\text { Favipravir almayan } \\
\text { (n:449) }\end{array}$ & Normal & $381(\% 84.9)$ & $234(\% 52.1)$ \\
& Yüksek $^{*}$ & $\mathbf{6 8}(\% 15.1)$ & $215(\% 47.9)$ \\
$\begin{array}{l}\text { Sadece favipravir } \\
\text { (n:257) }\end{array}$ & Normal & $246(\% 95.7)$ & $154(\% 59.9)$ \\
$\begin{array}{l}\text { Favipravir+antibiyotik } \\
\text { (n:595) }\end{array}$ & Yüksek & $\mathbf{1 1}(\% 4.3)$ & $103(\% 40.1)$ \\
P değeri & Yüksek & $\mathbf{4 9 1}(\% 82.5)$ & $287(\% 48.2)$ \\
& & $<0.001$ & 0.001 \\
\hline
\end{tabular}

Kruskal Wallis testi uygulanmıștır. ( ${ }^{*}$ ALP ve GGT değeri normalin 2 katını geçenler yüksek kabul edilmiştir).

\section{TARTIŞMA}

Çalışmamız sonunda yaklaşık her iki COVID-19 hastasından birinde $(\% 50,2)$ değișen derecelerde karaciğer enzim yüksekliği tespit ettik. COVID-19 tedavisinde kullanilan favipravirin diğer ilaç gruplarına kıyasla ciddi düzeyde enzim yüksekliği yapmadığını belirledik. Bu durum bize ilaca bağlı ALT-AST yüksekliği ve İBKH'ın favipravirden ziyade kullanılan antibiyotiklerle ve kullanılan ilaç sayısı ile ilişkili olduğunu göstermektedir.

Benzer şekilde hastaların GGT ve ALP düzeyi de tedavi başlangıcında her 3 grup arasında benzer olmasına rağmen COVID-19 tedavisi sonunda gruplar arasında anlamlı farklılı olduğu görüldü. Sadece favipravir alan hastalara kıyasla favipravirle birlikte antibiyotik kullanıldığında kolestaz enzimleri olan ALP ve GGT'de daha fazla yükselme meydana geldi. COVID-19 ve karaciğer hasarı ile ilgili 2273 hastayı içeren retrospektif bir kohort çalışmasında hastalar hafif, orta ve şiddetli(> 5 kat NÜS) karaciğer hasarı gelişenler diye sinıflandırılmış ve COVID-19'lu hastaların \%45'inde hafif, \%21'inde orta ve\%6,4'ünde ağır karaciğer hasarı meydana geldiği tespit edilmiştir. Oluşan karaciğer hasarı daha çok ilaçlar ve inflamasyon ile ilişkilendirilmiştir ${ }^{11}$.

COVID-19 ve karaciğer hasarının incelendiği 326 çalışmadan elde edilen 3772 hastalık bir metaanalizde ise karaciğer fonksiyon bozukluğu ile mortalite arasında ilişki olduğu sonucuna ulaşılmıștır. Özellikle kullanılan ilaçların ve COVID-19'un şiddetinin bu tabloda etkili olduğu belirtilmiștir ${ }^{12}$.

Favipravir ile ilgili literatürde çok fazla bilgi olmamasına rağmen COVID-19 tedavisinde kullanılan bütün ilaçların potansiyel hepatotoksik olduğu ifade edilmiş ve bu ilaçları tek veya kombine kullanırken karaciğer hasarı yönünden dikkatli olunması gerektiği vurgulanmiştır ${ }^{13}$.

İBKH ile ilgili yapılan başka bir çalışmada; İBKH'a bağlı sarılık ile gelen hastaların yaklaşık \%10'unda uzun vadede kronik karaciğer hastalığı ve siroz geliştiği sonucuna ulaşılmıştır ${ }^{14}$. Yine Amerikan ilaç ve gıda dairesi (FDA), 2009 yılında serum ALT- AST düzeyinde > 8 kat artış veya 2 haftadan uzun süren ve normalin 5 katından fazla ALT-AST yüksekliği veya ALT-AST'de 3 kattan fazla artışla birlikte total bilirubinde 2 kattan fazla artış veya ALTAST değerinde normalin 3 katından fazla artışla birlikte halsizlik, yorgunluk, sağ üst kadran hassasiyeti, ateş, bulantl, kusma, vücutta döküntüler (eozinofili de eşlik edebilir) gibi belirtilerin varlığında hepatotoksik ilacın kesilmesini önermiştir ${ }^{15}$.

Sonuç olarak COVID-19 tedavisinde ilaç kullanımına bağlı gelișen karaciğer fonksiyon bozukluklarında ön planda antibiyotiklerin rol oynadığını söyleyebiliriz. Tek başına favipravir kullanımı favipravirin diğer ilaçlarla kombine kullanımına göre karaciğer fonksiyonlarını daha az etkilemektedir. COVID-19 tedavisi sırasında karaciğer fonksiyon testlerinde yükselme veya İBKH tespit edildiğinde öncelikle karaciğer hasarının ciddiyeti, tipi (hepatik mi, kolestatik mi) ve İBKH gelişip gelişmediği değerlendirilmelidir. Hafif ve orta derecedeki karaciğer fonksiyon testlerinde yükselme olduğunda eğer hastanın tedavisi için önemliyse yakın takip altında ilaçlarına devam edilebilir. Fakat İBKH gelişen vakalarda hastanın 
tedavisindeki bütün potansiyel hepatotoksik ilaçlar kesilmelidir veya değiştirilmelidir. İlaçları kesmeye antibiyotiklerden başlamak akılcı bir yaklaşımdır. Hangi ilacın daha çok hepatotoksik olduğuna karar vermek için Livertox ( http://www.livertox.nih.gov $)^{16}$ veri tabanından faydalanılabilir.

Etik Kurul Kararı: Çalışmaya başlamadan önce Sağlık Bakanlığından izin ve hastanemiz etik kurulundan onay alındı. (Bakanlık izin No2020-06-05T10-40-24; Etik kurul: 16.10.2020 tarih ve 611 sayllı karar).

Çıkar Çatışması Beyanı: Yazarlar çıkar çatışması olmadığını bildirmişlerdir.

Finansal Destek: Bu çalışma her hangi bir fon tarafından desteklenmemiştir.

Declaration of Conflicting Interests: The authors declare that they have no conflict of interest.

Financial Disclosure: No financial support was received.

\section{KAYNAKLAR}

1. Centers for Disease Control and Prevention. Commercial Laboratory Seroprevalence Survey Data. https://www.cdc.gov/coronavirus/2019ncov/cases-updates/commercial-lab-surveys.html

2. Dong L., Hu S., Gao J. (2020). Discovering drugs to treat coronavirus disease 2019 (COVID-19). Drug Discoveries \& Therapeutics, 14; 58-60.

3. Li L, Jiang W, Wang JY. Clinical analysis of 275 cases of acute drug-induced liver disease. Front Med China. 2007; 1: 58-61

4. Hayashi PH, Fontana RJ. Clinical features, diagnosis, and natural history of drug-induced liver injury. Semin Liver Dis. 2014; 34: 134-44

5. Sleeman K, Mishin VP, Deyde VM, et al. In vitro antiviral activity of favipiravir (T-705) against drugresistant influenza and 2009 A(H1N1) viruses. Antimicrob Agents Chemother. 2010; 54: $2517 \mathrm{e} 2524$.
6. Shannon A, Selisko B, Le N, et al. Favipiravir Strikes the SARSCoV-2 at its Achilles Heel, the RNA Polymerase. bioRxiv; 2020 May 15.

7. Nagata $T$, Lefor AK, Hasegawa M, Ishii M: Favipiravir: a new medication for the Ebola virus disease pandemic. Disaster Med Public Health Prep. 2015 Feb; 9: 79-81.

8. Rosenke K, Feldmann H, Westover JB, et al: Use of Favipiravir to Treat Lassa Virus Infection in Macaques. Emerg Infect Dis. 2018 Sep; 24: 1696-9.

9. Pharmaceuticals and Medical Devices Agency: Avigan (favipiravir) Review Report/ Avigan Tablet 200 mg Favipiravir (JAN*) [Applicant] Toyama Chemical Co., Ltd. [Date of application] March 30, 2011

10. EASL. EASL clinical practice guidelines: druginduced liver injury. J Hepatol. 2019; 70: 1222-611.

11. Phipps MM, Barraza LH, LaSota ED, et al. Acute liver injury in COVID-19: Prevalence and association with clinical outcomes in a large US cohort. Hepatology. 2020 May 3010.1002/hep.31404.

12. Zeng-hong W. Dong liang Y.; A meta-analysis of the impact of COVID-19 on liver dysfunction European Journal of Medical Research volume 25, Article number: 54 (2020)

13. Olry A., Meunier L., Délire B., et al.; Drug Induced Liver Injury and COVID 19 Infection: The Rules Remain the Same Drug Saf. 2020 Jun 8: 1-3.

14. Güneydoğu Anadolu Bölgesindeki Üçüncü Basamak Gastroenteroloji Kliniğinin Toksik Hepatit Deneyimi Uçmak F., Tuncel E.T., Kaçmaz H., Ebik B., Kaya M.; Dicle Tip Dergisi / Dicle Medical Journal (2018) 45: 157-64.

15. Ford R, Schwartz L, Dancey J, US Food and Drug Administration; Center for Drug Evaluation and Research (CDER); Center for Biologics Evaluation and Research (CBER), et al. Guidance for industry: drug-induced liver injury-premarketing clinical evaluation. Eur J Cancer. 2009; 45: 268-74.

16. Hoofnagle JH, Serrano J, Knoben JE, et al. LiverTox: a website on drug-induced liver injury. Hepatology. 2013; 57: 873-4. 